УДК 630*114:630*228(477-25)

ФІЗИКО-ХІМІЧНІ ВЛАСТИВОСТІ ҐРУНТІВ У ЛІСОПАРКОВИХ НАСАДЖЕННЯХ М. КИЄВА

\author{
Кременецька Євгенія Олексіївна \\ кандидат сільськогосподарських наук, доцент \\ Сумський національний аграрний університет, м. Суми, Україна \\ ORCID: 0000-0001-5581-7868 \\ e.kremenetska@gmail.com \\ Мельник Андрій Васильович \\ доктор сільськогосподарських наук, професор \\ Сумський національний аграрний університет, м. Суми, Україна \\ ORCID: 0000-0001-7318-6262 \\ melnyk_ua@yahoo.com
}

Пробні площі закладалися у корінних лісостанах стиглого та перестійного віку в умовах $A_{2}, B_{2}, B_{3}, C_{2}, C_{3}, D_{2}$. Клімаксові лісостани збереглися завдяки існуванню лісопаркового поясу м. Києва. Вони сформовані Pinus sylvestris L. ma Quercus robur L. іє своєрідними еталонами продуктивності та біологічної стійкості.

У дерново-підзолистих глинисто-піщаних грунтах закономірним є зниження насиченості грунтово-поглинального комплексу (ГПК) катіонами лужно-земельних металів та водню від нижніх до верхніх шарів, відчутним є їхнє зростання при близькому заляганні моренних відкладів. Поверхневі шари вирізняються значними величинами, внаслідок акумуляції основ у процесі біокругообігу - до 3,3 мг-екв. на 100 г грунту.

У В2//' у гумусово-елювіальному шарі величина суми поглинутих основ досягає 5,25 мг-екв. на 100 г грунту, ємкість поглинання - 10,41, у В2 та В2/" сума поглинутих основ є незначною - 0,10-2,01, ємкість поглинання - 2,33-9,07 мг-екв. на 100 г грунту. Ступінь насичення основами у $C_{2}, C_{3}, D_{2}-$ до $82 \%$.

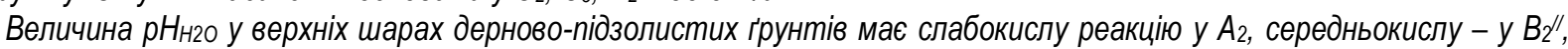
$B_{2}$ III, наближену до нейтральної - у $C_{2}, C_{3}$. Величина pHн2о збільшується із зростанням участі Q. robur L. y cкладi деревостанів, сприяє розвитку мікоризних грибів, живленню $P$. sylvestris $L$.

Величина рНксл у поверхневому шарі грунту під сосновими насадженнями знаходиться у межах сильнокислої (4,0_ 4,5), під сосново-дубовими - коливається між сильнокислою та слабокислою (4,6-5,2).

Досліджувані корінні лісостани характеризуються високим лісорослинним ефректом, який можна пояснити сприятливими величинами фрізико-хімічних властивостей грунтів ( $\mathrm{pH}_{\mathrm{H} 2 \mathrm{O}}$ р $\mathrm{pH}$ кс, сума поглинутих основ, ємкість поглинання, ступінь насичення основами). Отримані дані дозволяють скласти уяву про лісорослинний потенціал грунтів у вказаному регіоні та можуть бути врахованими у національній базі даних щодо лісових грунтів.

Ключові слова: лісові екосистеми, лісовий грунт, властивості грунтів, стиглі ліси, Україна.

DOI: https://doi.org/10.32845/agrobio.2019.1-2.3

Вступ. На сучасному етапі розвитку людства питання здоров'я лісів на планеті набуває особливого значення. Клімаксові ліси являють собою своєрідні еталони щодо продуктивності та біологічної стійкості, тому потребують уваги вчених. Важливим компонентом лісостану є лісовий грунт, оскільки ріст та продуктивність лісових біогеоценозів значною мірою залежать від лісорослинних властивостей ґрунтів [1]. Лісовий ґрунт старовікових лісостанів природного походження обумовлює високий лісорослинний ефект цих лісів. В умовах України клімаксові ліси збереглися переважно на територіях природно-заповідного фонду та у лісопаркових госпчастинах лісів зелених зон міст та селищ. Лісопарковий пояс м. Києва займає територію на межі Полісся та Лісостепу України, тому характеризується різноманітними лісорослинними умовами (від борів до дібров) та лісовими насадженнями, які формуються у цих умовах. Вивчення фізико-хімічних властивостей грунтів, які були сформовані під старовіковими корінними лісостанами дозволить скласти уяву про лісорослинний потенціал ґрунтів в умовах певної території. Отримані дані у подальшому можуть бути враховані у національній базі даних щодо лісових ґрунтів. У Швеції подібна інформація накопичується у базі даних щодо показників ґрунту та клімату [2].

Родючість лісових ґрунтів можна визначити як сукупність фізичних, хімічних та біологічних факторів, що характеризують здатність ґрунту продукувати біомасу [3]. Академік П. С.Погребняк був переконаний у тому, що «хімічна родючість» ґрунтів визначається, у першу чергу, показниками фрізико-хімічних та агрохімічних властивостей ґрунтів. Цим видатним українським лісівником-науковцем припущено та доведено той фракт, що наявність трофогенного ряду обумовлена формуванням ґрунтів із різною хімічною родючістю. Найбільш виразним є показник «сума поглинутих основ», який вказує на кількість ґрунтових колоїдів. До допоміжних показників ґрунтової родючості віднесено: «ємкість поглинання» та «кількість рухливих форм» $\mathrm{P}_{2} \mathrm{O}_{5}$ та $\mathrm{K}_{2} \mathrm{O}[4]$.

Терміни «якість ґрунтів» та «здоров'я ґрунтів» використовуються синонімічно, вони пов'язані з показниками щодо оцінки стану ґрунту (органічний вуглець ґрунту, збагаченість ґрунту поживними речовинами, ґрунтова біота тощо) [5]. Грунтознавцями встановлені взаємовідносини між типами лісорослинних умов та родючістю мінеральної та органогенної складових лісових ґрунтів [6].

До об'єктивних показників типів лісорослинних умов належать також: кількість фізичної глини та гумусу (в т·га-1), 
запас поживних речовин (в кг·га-1) та запас продуктивної вологи (в мм) у шарі ґрунту глибиною 0-100 см [7], механічний склад ґрунту та глибина максимального скупчення коріння дерев [8-10], глибина гумусованих горизонтів ґрунту [11], величина кислотності (pH) ґрунту [1215].

Органічна речовина, у т. ч. гумус здійснює множинні сприятливі впливи на фрізичні та фізико-хімічні властивості ґрунтів [16]. Підтверджено загальну тенденцію щодо підкислюючого впливу лісових насаджень - величина $\mathrm{pH}$ зменшується від 4,4-5,3 до 3,0 [17].

Індійські дослідники порівнювали ґрунти під час різних видів використання земель (ліс, сад, плантація, сільгоспугіддя) за такими показниками: індекс родючості ґрунту, коесріцієнт оцінки ґрунтів, наявні поживні речовини, обмінні катіони, мікробна активність тощо [18]. Найкращими виявилися показники ґрунтів, на яких зростають ліси.

Мета досліджень полягала в аналізі фрізико-хімічних властивостей грунтів $\left(\mathrm{pH}_{\mathrm{H} 2 \mathrm{O}}, \mathrm{pH}_{\mathrm{kCl}}\right.$, сума поглинутих основ, ємкість поглинання, ступінь насичення основами) під корінними лісостанами стиглого та перестійного віку, які зростають в різних типах лісорослинних умов $\left(A_{2}, B_{2}, B_{3}, C_{2}\right.$, $\mathrm{C}_{3}, \mathrm{D}_{2}$ ) у лісопаркових насадженнях м. Києва та поясненні причин високого лісорослинного ефекту цих лісостанів.

Матеріали і методи досліджень. Об'єкт дослідження - фрізико-хімічні властивості грунтів під лісостанами у різних типах лісорослинних умов. Предмет дослідження - стиглі та перестійні лісові насадження, які зростають у лісопарковому поясі міста Києва.

Пробні площі закладалися в корінних лісостанах стиглого та перестійного віку в різних типах лісорослинних умов - $A_{2}, B_{2}, B_{3}, C_{2}, C_{3}, D_{2}$. Вони розташовувалися в межах характерної для типу деревостану парцели. За Н. І. Базилевич та ін. [19] для досліджень підбиралася ділянка 3 деревостаном, який був би однорідним за всіма таксаційними показниками. Розподіл дерев за площею повинен бути рівномірним. Пробні площі (ПП) розміщувалися на відстані не менше ніж 30 метрів від квартальних просік, доріг та відкритих стін лісу. Їхня форма приймалася прямокутною - з відношенням сторін 1:2.

Враховуючи високі вікові стадії розвитку корінних лісостанів доцільно було не дотримуватися нормативів, що діють під час проведення лісотаксаційних досліджень. Закладка ПП проводилася 3 урахуванням вимог Д. В. Воробйова [20], Л. Є. Родіна, Н. П. Ремезова, Н.І. Базилевич [21] стосовно вивчення стиглих та перестійних лісостанів. Величина ПП дорівнювала 0,5 га. Саме такий розмір $(50 \times 100 \mathrm{~m})$ дозволив врахувати парцелярну структуру лісостанів та стадію рекреаційної дигресії.

Лісівницько-таксаційну характеристику пробних площ та місця їхньої локації наведено у табл. 1.

Лісівницько-таксаційна характеристика пробних площ

\begin{tabular}{|c|c|c|c|c|c|c|c|}
\hline $\begin{array}{c}\text { №№ } \\
П П \\
\end{array}$ & $\begin{array}{l}\text { Тип } \\
\text { лісу } \\
\end{array}$ & Місцезнаход-ження ПП & Ярус & Склад порід & Вік, років & Повнота & Бонітет \\
\hline 1 & $\mathrm{~A}_{2} \mathrm{C}$ & ЛПГ “К-3”, Дачне, кв.81, в.4 & 1 & $10 C_{3}$ & 95 & 0,48 & III \\
\hline 2 & $\mathrm{~B}_{2} / /$ & СЛПГ, Пуща-Водицьке, кв. 36, в. 3 & 1 & $10 \mathrm{C}_{3}$ & 140 & 0,65 & II \\
\hline 3 & $\mathrm{~B}_{2} / /$ & ЛПГ “К-3”, Дачне, кв.76, в. 12 & 1 & 10С3+Бп & 140 & 0,57 & II \\
\hline 4 & $\mathrm{~B}_{2}^{\prime \prime}$ & ДЛПГ, Дніпровське, кв.31, в. 36 & 1 & $10 \mathrm{C}_{3}$ & 130 & 0,71 & II \\
\hline 5 & $\mathrm{~B}_{2}^{\prime \prime}$ & СЛПГ,Межигірське, кв. 68, в. 7 & 1 & $10 \mathrm{C}_{3}$ & 140 & 0,44 & I \\
\hline 6 & $\mathrm{~B}_{2} / 1$ & ДЛПГ, Микільське, кв.45, в. 9 & 1 & $10 \mathrm{C}_{3}+\mathrm{Z}_{3}$ & 150 & 0,60 & II \\
\hline 7 & $\mathrm{~B}_{2}^{\prime \prime \prime}$ & БЛДС, Дзвінківське, кв. 9, в. 7 & $\begin{array}{l}1 \\
2\end{array}$ & $\begin{array}{c}10 \mathrm{C}_{3}+Б п \\
\text { 8Дз2Лпд+Клг, Взг, Гз }\end{array}$ & $\begin{array}{l}165 \\
90\end{array}$ & $\begin{array}{l}0,86 \\
0,24\end{array}$ & la \\
\hline 8 & $\mathrm{~B}_{3} \mathrm{LC}$ & ЛПГ “К-3”, Дачне, кв. 64, в. 17 & 1 & $10 C_{3}$ & 120 & 0,68 & 1 \\
\hline 9 & $\mathrm{C}_{2}$ ГДС & СЛПГ, Київське, кв. 51, в. 7 & 1 & $9 \mathrm{C}_{3} 1 Д 3+Б п$ & 150 & 0,69 & 1 \\
\hline 10 & $\mathrm{C}_{2} Г Д С$ & ДЛПГ, Микільське, кв. 35, в. 5 & 1 & 7Сз3Дз & 150 & 0,42 & 1 \\
\hline 11 & $\mathrm{C}_{2} Г \mathrm{CД}$ & СЛПГ, Київське, кв. 57, в. 2 & 1 & $8 Д_{3} 2 \mathrm{C}_{3}$ & 110 & 0,78 & II \\
\hline 12 & $\mathrm{C}_{2} Г \mathrm{CД}$ & ДЛПГ, Броварське, кв. 60, в. 11 & 1 & $10 Д_{3}+C_{3}$ & 110 & 0,78 & 1 \\
\hline 13 & $\mathrm{~B}_{2} / \mathrm{I}$ & БЛДС, Боярське, кв. 33, в. 8 & 1 & $10 C_{3}$ & 160 & 0,73 & II \\
\hline 14 & $\mathrm{C}_{3} Г Д С$ & ДЛПг, Білодібровне, кв. 40, в.1 & $\begin{array}{l}1 \\
2 \\
\end{array}$ & $\begin{array}{c}8 \mathrm{C} 32 Д 3 \\
6 \mathrm{~B} 3 г 4 К л г \\
\end{array}$ & $\begin{array}{l}160 \\
70 \\
\end{array}$ & $\begin{array}{l}0,58 \\
0,30 \\
\end{array}$ & la \\
\hline 15 & $\mathrm{C}_{3} Г \mathrm{CД}$ & СЛПГ, Святошинське, кв. 94, в. 4 & 1 & $10 Д_{3}+\mathrm{C}_{3}, \mathrm{Oc}$ & 110 & 0,83 & 1 \\
\hline 16 & $\mathrm{C}_{3} Г С Д$ & СЛПГ, Межигірське, кв. 60, в. 11 & 1 & $10 Д_{3}+C_{3}$ & 95 & 0,60 & 1 \\
\hline 17 & $\mathrm{D}_{2}$ ГД & ЛПГ “К-3”,Голосієвське, кв. 43, в. 2 & 1 & $10 Д 3$ & 140 & 0,69 & $\|$ \\
\hline
\end{tabular}
дослідна станція.

Оцінка фізико-хімічних властивостей ґрунтів включала визначення: pH водної та сольової витяжки - 
Гільковицем.

Зразки грунту відбиралися з липня по вересень (при умові сухої погоди), тобто в осінній строк переданабіотичного періоду. Обмеження глибини відбору мішаних зразків в межах одного метра можна пояснити тим, що більша кількість всисних корінців розміщена, за І. І. Смольяніновим [22], саме до глибини 0,7-1,0 м. Після закладання грунтового розрізу із кожного генетичного горизонту до глибини $100 \mathrm{~cm}$ відбиралися зразки ірунту: для визначення об'ємної маси -у непорушеному стані за допомогою ґрунтових циліндрів об'ємом $500 \mathrm{~cm}^{3} \quad$ (з 5-разовою повторністю), для лабораторних досліджень готувалися мішані зразки.

При морфологічному описі ґрунтового розрізу встановлювалася середина кожного генетичного горизонту. На стінку ґрунтової товщі по відношенню до цієї лінії, відступаючи вверх та вниз по $5 \mathrm{~cm}$, наносили границі генетичного горизонту. В межах цієї границі відбирався індивідуальний зразок. Він ретельно перемішувався на листі паперу. Далі склянкою відмірялася середня проба біля $200 \mathrm{~cm}^{3}$ і зсипалася у мішечок. Таким чином готувалися й 2-й, 3-й, 4-й, 5-й індивідуальні зразки. Для отримання мішаного зразку вони зсипалися разом та ретельно перемішувалися. Підготовка відібраного мішаного зразку до лабораторного аналізу зводилася до видалення 3 нього домішок та новоутворень, висушування при кімнатній температурі до повітряно-сухого стану та просівання через сито з діаметром отворів 1,0 мм [23].

Результати та їх обговорення. Лісопаркові насадження м. Києва зростають на межі Полісся та Лісостепу України, тому вони характеризуються різноманітними типами лісорослинних умов. Найбільш розповсюдженими $є$ едатопи: свіжий субір $\left(\mathrm{B}_{2}\right)$, свіжий сугруд $\left(\mathrm{C}_{2}\right)$, вологий сугруд $\left(\mathrm{C}_{3}\right)$. Корінні лісостани бідної відміни свіжого субору $\left(\mathrm{B}_{2}{ }^{\prime}\right)$ - сосняки I-III бонітетів, середньої відміни свіжого субору $\left(\mathrm{B}_{2} /\right)$ -

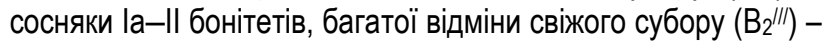
сосняки la бонітету із другим ярусом із Q. robur, добре розвиненим підліском Coryllus avellana L. B умовах свіжого та вологого сугруду коріння насадження мають 2 яруси: перший - створений P. sylvestris I-la бонітетів зі значною участю Q. robur, другий - сфоормований Q. robur, Tilia cordata Mill., Acer pseudoplatanus L. та Sorbus aucuparia L., а також підростом із Betula pendula Roth. Невеликі площі займають сухі та свіжі борові умови $\left(\mathrm{A}_{1}, \mathrm{~A}_{2}\right)$, де зростають сосняки III бонітету. У свіжій діброві корінними є дубняки II-III бонітету 3 другим ярусом із Carpinus betulus L., T. cordata, A. pseudoplatanus та підліском із $C$. avellana, Acer tataricum L., Euonymus verrucosa Scop., E. europaea L.

Детальне вивчення ірунтових умов засвідчило, що корінні насадження лісопаркового поясу м. Києва в умовах борів, суборів та сугрудів зростають на дерновослабопідзолистих свіжих глинисто-піщаних або супіщаних ґрунтах, які сфрормувалися на флювіогляціальних наносах та на різній глибині мають суглинкові прошарки неоднакової товщини, іноді підстилаються мореною. В окремих едатопах трапляються дерново-підзолисті глеюваті глинисто-піщані грунти (B) та глеюваті супіщані $\left(\mathrm{C}_{3}\right)$. У свіжому груді переважають сірі лісові суглинки, які утворилися на лесі.

За даними табл. 2 в умовах $\mathrm{A}_{2}$ на пробній площі № 1 (ПП №1) кислотність водної витяжки (рНнго) генетичних горизонтів ґрунту слабокисла $(6,0)$ з незначним коливанням у бік нейтральної в елювіальному горизонті $(6,2)$ та слабокислою у материнській породі $(5,9)$. За величиною

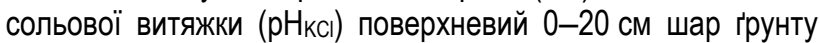
сильнокислий, а всі нижче розташовані - слабокислі. Поверхневий шар ґрунту характеризується також найбільшою гідролітичною кислотністю $(5,8)$ та ємкістю поглинання (8,55 мг-екв. на 100 г грунту). У боровому піску материнська порода має незначну суму основ, близько 3,6 мг-екв. на 100 г ірунту. Це у декілька разів більше, ніж у вище розташованих шарах ілювіального горизонту, використаних попередньою життєдіяльністю соснового лісостану.

Фізико-хімічні властивості грунтів в умовах свіжого бору

\begin{tabular}{|c|c|c|c|c|c|c|}
\hline \multirow{2}{*}{$\begin{array}{c}\text { Глибина взяття } \\
\text { зразків, см }\end{array}$} & \multicolumn{2}{|c|}{$\mathrm{pH}$} & Гідролітична кислотність & $\begin{array}{c}\text { Сума поглинутих } \\
\text { основ }\end{array}$ & Ємкість поглинання & $\begin{array}{c}\text { Ступінь насичення } \\
\text { основами, } \\
\%\end{array}$ \\
\cline { 2 - 6 } & $\mathrm{H}_{2} \mathrm{O}$ & $\mathrm{KCl}$ & \multicolumn{5}{c|}{ мг-екв. на 100 г грунту } \\
\hline \multicolumn{7}{|c|}{ Пробна площа № 1 } \\
\hline $0-20$ & 5,0 & 4,0 & 5,80 & 2,75 & 8,55 & 32,3 \\
\hline $2-50$ & 5,0 & 5,2 & 1,76 & 0,90 & 2,66 & 34,0 \\
\hline $50-64$ & 6,2 & 5,3 & 1,05 & 0,40 & 1,45 & 27,6 \\
\hline $64-100$ & 5,9 & 5,1 & 0,88 & 3,61 & 1.49 & 59,1 \\
\hline
\end{tabular}

Наведені у табл. 3 дані свідчать про те, що дерновопідзолисті ґрунти свіжого субору мають кислу реакцію. Такий рівень кислотності можливий при надходженні значної кількості органічних кислот у процесі розкладу лісової підстилки. Актуальна та обмінна кислотності ґумусовоелювіального горизонту в умовах $\mathrm{B}_{2} /$ вирізняються дещо більшими значеннями - перша коливається в межах слабо кислої (5,0-5,8), а друга змінюється від 3,9 до 4,8. Кислотність має тенденцію до нейтралізації 3 глибиною ґрунту. Так, у нижче розташованих горизонтах $\mathrm{pH}_{\text {20 }}$ досягає величини 6,1 , а $\mathrm{pH}_{\mathrm{KCl}}-5,7$. 
Таблиця 3

Фізико-хімічні властивості грунтів в умовах свіжого субору

\begin{tabular}{|c|c|c|c|c|c|c|}
\hline \multirow[t]{2}{*}{$\begin{array}{l}\text { Глибина взяття } \\
\text { зразків, см }\end{array}$} & \multicolumn{2}{|c|}{$\mathrm{pH}$} & \multirow[t]{2}{*}{$\begin{array}{c}\text { Гідролітична } \\
\text { кислотність }\end{array}$} & $\begin{array}{c}\text { Сума поглинутих } \\
\text { основ }\end{array}$ & \multirow[t]{2}{*}{$\begin{array}{c}\text { Ємкість } \\
\text { поглинання }\end{array}$} & \multirow[t]{2}{*}{$\begin{array}{c}\text { Ступінь насичення } \\
\text { основами, } \\
\% \\
\end{array}$} \\
\hline & $\mathrm{H}_{2} \mathrm{O}$ & $\mathrm{KCl}$ & & мг-екв. на 100 г ґру & & \\
\hline \multicolumn{7}{|c|}{ Середня відміна свіжого субору $\left(\mathrm{B}_{2}{ }^{\prime \prime}\right)$} \\
\hline \multicolumn{7}{|c|}{ Пробна площа №2 } \\
\hline $0-14$ & 4,7 & 4,0 & 7,74 & 0,10 & 7,84 & 1,3 \\
\hline 14-33 & 5,5 & 5,0 & 2,46 & 0,10 & 2,56 & 3,9 \\
\hline $33-69$ & 5,6 & 5,1 & 1,32 & 0,20 & 1,52 & 13,2 \\
\hline $69-93$ & 6,3 & 5,2 & 0,70 & 0,50 & 1,20 & 41,7 \\
\hline $93-100$ & 6,1 & 5,3 & 0,53 & 1,50 & 2,03 & 74,1 \\
\hline \multicolumn{7}{|c|}{ Пробна площа №3 } \\
\hline $0-7$ & 5,3 & 4,8 & 8,97 & 0,10 & 9,07 & 1,1 \\
\hline $7-35$ & 5,7 & 4,8 & 2,29 & 2,01 & 4,30 & 46,8 \\
\hline $35-60$ & 5,8 & 5,3 & 0,96 & 0,50 & 1,46 & 34,2 \\
\hline $60-100$ & 6,1 & 5,3 & 0,70 & 0,70 & 1,40 & 50,0 \\
\hline \multicolumn{7}{|c|}{ Пробна площа №4 } \\
\hline $0-8$ & 5,8 & 4,5 & - & 0,88 & - & - \\
\hline $8-12$ & 5,9 & 5,2 & 1,93 & 0.40 & 2,33 & 17,2 \\
\hline $12-51$ & 6,0 & 5,2 & 0,88 & 0.50 & 1,38 & 36,4 \\
\hline $51-100$ & 6,0 & 5,3 & 0,57 & 0,60 & 1,17 & 51,4 \\
\hline \multicolumn{7}{|c|}{ Пробна площа №5 } \\
\hline $0-5$ & 5,0 & 4,4 & 5,63 & 0,10 & 5,73 & 1,8 \\
\hline $5-16$ & 5,5 & 4,8 & 2,33 & 1,00 & 3,33 & 30,1 \\
\hline $16-51$ & 5,7 & 5,2 & 1,93 & 1,30 & 3,23 & 40,3 \\
\hline $51-100$ & 6,1 & 5,3 & 0,53 & 1,00 & 1,53 & 65,6 \\
\hline \multicolumn{7}{|c|}{ Пробна площа №6 } \\
\hline $0-9$ & 5,1 & 3,9 & - & 0,47 & - & - \\
\hline $9-34$ & 5,3 & 4,7 & 2,98 & 1,30 & 4,28 & 30,4 \\
\hline $34-72$ & 6,0 & 5,2 & 1,75 & 0,50 & 2,25 & 22,2 \\
\hline $72-100$ & 6,0 & 5,7 & 0,44 & 0,35 & 0,79 & 44,4 \\
\hline \multicolumn{7}{|c|}{ Багата відміна свіжого субору $\left(\mathrm{B}_{2} / / 1\right)$} \\
\hline \multicolumn{7}{|c|}{ Пробна площа №7 } \\
\hline $0-5$ & 4,9 & 4,3 & 5,16 & 5,25 & 10,41 & 50,4 \\
\hline $5-10$ & 4,8 & 4,0 & 5,60 & 3,05 & 8,65 & 35,3 \\
\hline $20-30$ & 5,3 & 4,4 & 2,59 & 0,40 & 2,99 & 20,0 \\
\hline $60-70$ & 4,6 & 3,7 & 4,11 & 3,70 & 7,81 & 47,1 \\
\hline
\end{tabular}

Дані ґрунти характеризуються незначною сумою поглинутих основ. Помітним $€$ те, що цей показник збільшується паралельно наростанню трофності ґрунту, набуваючи максимуму у $\mathrm{B}_{2}{ }^{\prime \prime \prime}-5,25$ мг-екв. на 100 г ґрунту. У ґрунтах бідної та середньої відміни свіжого субору цей показник не перевищує 2,0 мг-екв. на 100 г грунту.

Ємкість поглинання знижується від верхніх горизонтів грунтового профрілю до нижніх. Виключення належить багатій відміні свіжого субору $\left(\mathrm{B}_{2} / /\right)$, де на глибині 60-70 см вона зростає у 2,5 рази, порівняно 3 вище розташованим горизонтом. Це явище можна пояснити близьким заляганням морени, якій притаманним є підвищений вміст основ. Крім того, цей приклад цікавий тим, що ступінь насичення основами на глибині 60-70 cм $є$ майже однаковим із наведеним у поверхневому 5-см шарі - близько $50 \%$.

у дерново-підзолистих грунтах в результаті вимивання основ атмосферними опадами та біологічного виносу за участі густої мережі деревного коріння із верхніх горизонтів, основи накопичуються у нижніх.

Звертає на себе увагу величина $\mathrm{pH}_{\kappa \mathrm{cl}}, \mathrm{y}$ поверхневому шарі вона дорівнює 4,2. Спираючись на дані табл. 4, можна відмітити, що, в цілому, величини фізикохімічних властивостей цих ґрунтів відповідають закономірностям, які були встановлені для дерновослабопідзолистих глеюватих грунтів [24].

Таблиця 4

Фізико-хімічні властивості ґрунтів в умовах вологого субору

\begin{tabular}{|c|c|c|c|c|c|c|}
\hline \multirow{2}{*}{$\begin{array}{c}\text { Глибина взяття } \\
\text { зразків, см }\end{array}$} & \multicolumn{2}{|c|}{$\mathrm{pH}$} & \multicolumn{1}{|c|}{ Гідролітична кислотність } & $\begin{array}{c}\text { Сума поглинутих } \\
\text { основ }\end{array}$ & Ємкість поглинання & $\begin{array}{c}\text { Ступінь насичення } \\
\text { основами, } \\
\%\end{array}$ \\
\cline { 2 - 6 } & $\mathrm{H}_{2} \mathrm{O}$ & $\mathrm{KCl}$ & \multicolumn{5}{|c|}{ мг-екв. на 100 г грунту } \\
\hline \multicolumn{7}{|c|}{ Пробна площа №8 } \\
\hline $0-20$ & 5,2 & 4,2 & 8,27 & 0,20 & 8,47 & 2,4 \\
\hline $20-50$ & 5,7 & 5,0 & 3,01 & 1,82 & 4,83 & 37,7 \\
\hline $50-62$ & 6,1 & 5,2 & 1,40 & 0,50 & 1,90 & 26,3 \\
\hline $62-100$ & 6,1 & 5,3 & 0,70 & 0,70 & 1,40 & 50,0 \\
\hline
\end{tabular}


Дерново-середньопідзолисті ґрунти свіжого сугруду є менш кислими, порівняно з дерново-слабопідзолистими ґрунтами свіжих суборів, хоча ступінь розвитку підзолистого процесу є більш глибшим. Можливо, такий стан пов'язаний $з$ відсутністю оглеєння та незначним вмістом рухомого алюмінію. Однією з причин такого поліпшення ґрунтових умов $€$ те, що розклад органічних решток відбувається у аеробних умовах.

В табл. 5 наведено дані для порівняння величини

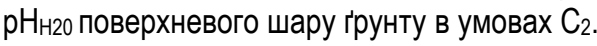

Таблиця 5

Фізико-хімічні властивості ґрунтів в умовах свіжого сугруду

\begin{tabular}{|c|c|c|c|c|c|c|}
\hline \multirow{2}{*}{$\begin{array}{c}\text { Глибина взяття } \\
\text { зразків, см }\end{array}$} & \multicolumn{2}{|c|}{$\mathrm{pH}$} & $\begin{array}{c}\text { Гідролітична } \\
\text { кислотність }\end{array}$ & $\begin{array}{c}\text { Сума поглинутих } \\
\text { основ }\end{array}$ & Ємкість поглинання & \multirow{2}{*}{$\begin{array}{c}\text { Ступінь насичення } \\
\text { основами, } \\
\% \\
\end{array}$} \\
\hline & $\mathrm{H}_{2} \mathrm{O}$ & $\mathrm{KCl}$ & \multicolumn{3}{|c|}{ мг-екв. на 100 г ґрунту } & \\
\hline \multicolumn{7}{|c|}{ Пробна площа №9 } \\
\hline $0-17$ & 5,0 & 4,2 & 9,01 & 0,58 & 9,59 & 6,0 \\
\hline $17-38$ & 5,9 & 5,3 & 1,75 & 3,30 & 4,05 & 56,8 \\
\hline $38-55$ & 5,8 & 5,2 & 0,88 & 1,20 & 2,08 & 57,8 \\
\hline $55-100$ & 6,0 & 5,3 & 0,44 & 0,30 & 0,74 & 40,7 \\
\hline \multicolumn{7}{|c|}{ Пробна площа №10 } \\
\hline $0-12$ & 5,5 & 5,2 & 7,04 & 0,78 & 7,82 & 9,9 \\
\hline $12-52$ & 5,8 & 5,2 & 1,93 & 2,11 & 4,04 & 52,2 \\
\hline $52-73$ & 6,0 & 5,1 & 1,23 & 0,50 & 1,73 & 29,0 \\
\hline $73-100$ & 5,9 & 5,3 & 1,75 & 1,60 & 3,35 & 47,8 \\
\hline \multicolumn{7}{|c|}{ Пробна площа №11 } \\
\hline $0-16$ & 5,7 & 4,6 & 5,63 & 1,80 & 7,43 & 24,2 \\
\hline $16-21$ & 6,5 & 5,2 & 1,76 & 0,20 & 1,96 & 10,3 \\
\hline $21-60$ & 5,6 & 5,2 & 1,73 & 0,20 & 1,93 & 10,4 \\
\hline $60-87$ & 5,8 & 5,4 & 0,79 & 0,70 & 1,49 & 47,1 \\
\hline $87-100$ & 6,4 & 5.6 & 0,44 & 0,50 & 0,94 & 53,3 \\
\hline \multicolumn{7}{|c|}{ Пробна площа №12 } \\
\hline $0-10$ & 5,9 & 5,0 & 5,80 & 3,33 & 9,13 & 36,4 \\
\hline $9-58$ & 5,3 & 4,6 & 2,98 & 0,50 & 3,48 & 14,4 \\
\hline $58-82$ & 5,4 & 4,8 & 2,46 & 1,60 & 4,06 & 39,5 \\
\hline $82-90$ & 6,4 & 4,5 & 0,53 & 2,30 & 2,83 & 81,4 \\
\hline $90-100$ & 5,6 & 4,6 & 2,74 & 2,83 & 5,57 & 50,8 \\
\hline
\end{tabular}

Помітно, що слабокисла реакція змінюється в бік нейтральної пропорційно щодо збільшення у складі деревостанів участі Q. robur. Якщо розглянути цю особливість детальніше, то можна простежити наступний ряд величин $\mathrm{pH}_{22}$ згідно зі співвідношенням часток Q. robur та $P$. sylvestris у складі деревостану: одна частка $Q$. robur та дев'ять часток $P$. sylvestris - 5,0; три частки $Q$. robur та сім часток $P$. sylvestris - 5,5; вісім часток $Q$. robur та 2 частки $P$. sylvestris - 5,7; десять часток $Q$. robur $-5,9$.

Приблизно таким же чином змінюється гідролітична кислотність - від 9,0 до 5,8 мг-екв. на 100 г грунту. 3 цього ряду випадає величина показника, що дорівнює 7,0 мгекв. на 100 г грунту. На нашу думку, таке завищення гідролітичної кислотності у ґрунті під чисто дубовим деревостаном викликане процесом оглеєння ґрунтового профрілю.
Суми поглинутих основ під різними деревостанами $€$ близькими за величинами. Вони змінюються від 0,2 до 3,3 мг-екв. на 100 г ґрунту. Ємкість поглинання має найбільші величини у поверхневому шарі. Ї̈̈ величина зменшується 3 глибиною ґрунтового профрілю. Ступінь насичення основами $€$ значним майже у всіх генетичних горизонтах.

На основі даних табл. 6, можна сказати, що фізикохімічні властивості ґрунтів в умовах вологого сугруду мають певні відміни. В першу чергу, це стосується величин актуальної кислотності, які помітно відрізняються у поверхневому шарі. Слід зауважити, що живий надґрунтовий покрив та підлісочний ярус в умовах вологого сугруду представлені практично тими самими видами, що i y лісостанах свіжого сугруду. 
Фізико-хімічні властивості ґрунтів в умовах вологого сугруду

\begin{tabular}{|c|c|c|c|c|c|c|}
\hline \multirow{2}{*}{$\begin{array}{c}\text { Глибина взяття } \\
\text { зразків, см }\end{array}$} & \multicolumn{2}{|c|}{$\mathrm{pH}$} & Гідролітична кислотність & $\begin{array}{c}\text { Сума поглинутих } \\
\text { основ }\end{array}$ & $\begin{array}{c}\text { Ємкість } \\
\text { поглинання }\end{array}$ & \multirow{2}{*}{$\begin{array}{c}\text { Ступінь насичення } \\
\text { основами, } \\
\%\end{array}$} \\
\hline & $\mathrm{H}_{2} \mathrm{O}$ & $\mathrm{KCl}$ & \multicolumn{3}{|c|}{ мг-екв. на 100 г грунту } & \\
\hline \multicolumn{7}{|c|}{ Пробна площа №13 } \\
\hline $0-16$ & 5,3 & 5,9 & 4,56 & 0,10 & 4,66 & 2,2 \\
\hline $16-58$ & 5,2 & 5,4 & 4,28 & 5,40 & 9,68 & 55,8 \\
\hline $58-100$ & 4,6 & 4,2 & 8,49 & 15,49 & 23,98 & 64,6 \\
\hline \multicolumn{7}{|c|}{ Пробна площа №14 } \\
\hline $0-9$ & 5,4 & 3,9 & 9,52 & 1,39 & 10,91 & 12,8 \\
\hline $9-19$ & 5,9 & 5,3 & 2,29 & 3,52 & 5,81 & 60,6 \\
\hline $19-75$ & 5,7 & 5,0 & 1,93 & 1,00 & 2,93 & 34,2 \\
\hline $75-100$ & 6,2 & 5,4 & 1,41 & 2,52 & 3,93 & 64,1 \\
\hline \multicolumn{7}{|c|}{ Пробна площа №15 } \\
\hline $0-12$ & 6,4 & 4,8 & 3,87 & 1,80 & 5,67 & 31,7 \\
\hline $12-32$ & 5,4 & 4,6 & 2,98 & 2,21 & 5,19 & 42,5 \\
\hline $32-62$ & 5,8 & 4,1 & 1,32 & 0,50 & 1,82 & 27,6 \\
\hline $62-85$ & 6,2 & 4,9 & 0,44 & 0,90 & 1,34 & 67,3 \\
\hline $85-100$ & 6,3 & 5,4 & 1,06 & 4,94 & 6,00 & 82,4 \\
\hline \multicolumn{7}{|c|}{ Пробна площа №16 } \\
\hline $0-4$ & 5,9 & 4,6 & 7,04 & 1,29 & 8,33 & 15,5 \\
\hline $4-21$ & 5,4 & 4,8 & 2,63 & 2,01 & 4,64 & 43,2 \\
\hline $21-36$ & 5,6 & 4,7 & 2,02 & 0,30 & 2,32 & 13,0 \\
\hline $36-66$ & 5,9 & 5,2 & 2,37 & 0,30 & 2,67 & 11,3 \\
\hline $66-100$ & 6,1 & 4,9 & 1,32 & 0,20 & 1,52 & 13,2 \\
\hline
\end{tabular}

У забезпеченні рівня кислотності ґрунту вирішальну роль відіграє щорічний опад деревостану. Отже, в цих умовах, величина рНн2о залежить від складу деревостану, яка $€$ переважно слабокислою, інколи - близькою до нейтральної. Допоміжну роль у створенні такої реакції відіграє підлісочний ярус, який сформований переважно видами (C. avellana, E. verrucosa, Sambucus nigra L.), опад яких спричиняє інтенсивний підлугуючий вплив на лісову підстилку та ґрунт [25].

У поверхневому шарі ґрунтів реакція актуальної кислотності $є$ різною. Під впливом 110-річного деревостану із Q. robur $з$ домішкою P. sylvestris та Alnus glutinosa (L.) Gaertn., реакція $\mathrm{pH}_{20}$ наближається до нейтральної $(6,4)$. Під двоярусним деревостаном 3 переважанням $P$. sylvestris у першому ярусі та значною участю $A$. platanoides - у другому, реакція рНн20 знаходиться в межах слабокислої $(5,4)$. Із літературних джерел [26] відомо, що P. sylvestris та A. platanoides відносяться до порід-підкислювачів грунту. Реакція $\mathrm{pH}_{220}$, яка була близькою до нейтральної у поверхневому шарі, з глибиною стає слабокислою $(5,4-5,8)$, а у морені знову наближається до нейтральної $(6,2-6,3)$.

Обмінна кислотність верхніх генетичних горизонтів $€$ слабокислою та середньокислою. У моренному суглинку набуває сильнокислої реакції ( $\left.\mathrm{pH}_{\mathrm{H} 20}-4,6 ; \mathrm{pH}_{\text {ксl }}-4,2\right)$.

Погребняк П. С. у роботі "Дослідження грунтів і кореневих систем в лісах Полісся Української РСР" [4] пояснював такий випадок тим, що у шарі валунного суглинку (починається 3 глибини $58 \mathrm{~cm}$ ), збільшується кількість всисних корінців. Вони перехоплюють основи, що вимиваються із підстилки та верхнього шару грунту. А це впливає на підвищення гідролітичної кислотності - від 4,28 до 8,49 мг-екв. на 100 г ґрунту, суми поглинутих основ - від 5,40 до 15,49 та ємкості поглинання - від 9,68 до 23,98 мг-екв. на 100 г грунту.

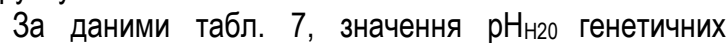
горизонтів грунтового розрізу відповідають закономірностям, які були встановлені П. С. Погребняком для грунтів дібровного (грудового) типу [4]. Реакція лісової підстилки (в умовах свіжого груду) і продуктів ії розкладу найчастіше

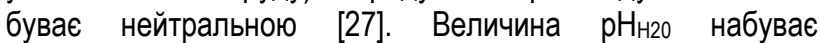
максимального значення $(6,6)$ у гумусово-елювіальному горизонті, який $є$ пухким та добре аерованим. Від нього донизу йде швидке підкислення реакції. У шарі 20-40 см виявлений мінімум $\mathrm{pH}_{20}(4,7)$, що простягається і нижче. Деяка нейтралізація відмічена при наближенні до ґрунтотвірної породи $(5,4-6,0)$.

Таблиця 7

Фізико-хімічні властивості ґрунтів в умовах свіжого груду

\begin{tabular}{|c|c|c|c|c|c|c|}
\hline \multirow{2}{*}{$\begin{array}{c}\text { Глибина взяття зразків, } \\
\text { см }\end{array}$} & \multicolumn{2}{|c|}{$\mathrm{pH}$} & $\begin{array}{c}\text { Гідролітична } \\
\text { кислотність }\end{array}$ & $\begin{array}{c}\text { Сума поглинутих } \\
\text { основ }\end{array}$ & $\begin{array}{c}\text { Ємкість } \\
\text { поглинання }\end{array}$ & $\begin{array}{c}\text { Ступінь насичення } \\
\text { основами, } \\
\%\end{array}$ \\
\cline { 2 - 6 } & $\mathrm{H}_{2} \mathrm{O}$ & $\mathrm{KCl}$ & \multicolumn{5}{|c|}{ мг-екв. на 100 г грунту } \\
\hline \multicolumn{7}{|c|}{ Пробна площа №17 } \\
\hline $0-20$ & 6,6 & 4,8 & 7,95 & 5,70 & 13,65 & 41,8 \\
\hline $20-40$ & 4,7 & 4,5 & 9,01 & 8,89 & 17,90 & 41,6 \\
\hline $40-62$ & 5,4 & 4,1 & 4,42 & 7,68 & 6,10 & 63,5 \\
\hline $62-100$ & 6,0 & 4,4 & 2,48 & 4,25 & 63,2 \\
\hline
\end{tabular}

Поверхневий шар характеризується також $\mid$ реакцію $(4,8)$. Із глибиною вона поступово зменшується, максимальними значеннями $\mathrm{pH}$ кс, яка має середньокислу 1 досягаючи мінімального значення в елювіальному горизонті, 
де $\mathrm{pH}$ кс $є$ сильнокислою $(4,1)$. Порівняно висока гідролітична кислотність верхніх горизонтів (7,95-9,01 мг-екв. на 100 г ґрунту), як правило, обумовлюється дією органічних кислот. Зменшення її величини у глибших горизонтах $(4,48-2,48)$ викликане карбонатністю ґрунтової породи - лесовидними суглинками.

У 2006 році Є. О. Кременецькою [28] здійснювалося порівняння (для умов Дзвінківського лісництва Боярської ЛДС Київської області) фрізико-хімічних та агрохімічних властивостей ґрунту у середньовікових штучних соснових насадженнях мішаного складу із старовіковими корінними лісостанами. Встановлено, що фізико-хімічні властивості ґрунту під 40-річними штучними сосновими насадженнями ще не набули величин, які притаманні природним еталонним лісам перестійного віку, що зростають в аналогічних умовах - у багатій відміні свіжого субору (едатоп $\left.\mathrm{B}_{2}{ }^{\prime \prime \prime}\right)$.

Висновки. Серед лісостанів, які зростають в умовах свіжого субору (едатоп $B_{2}$ ) характеризуються найбільшими величинами суми поглинутих основ та ємкості поглинання (відповідно 5,25 мг-екв. на 100 г грунту та 10,41 мг-екв. на 100 г грунту), які були встановлені в гумусово-елювіальному шарі багатої різниці (едатоп $\left.\mathrm{B}_{2} / / /\right)$. У едатопах $\mathrm{B}_{2} /$ та $\mathrm{B}_{2} /$ сума поглинутих основ $€$ незначною - 0,10-2,01 мг-екв. на 100 г ґрунту, при цьому ємкість поглинання становить 2,339,07 мг-екв. на 100 г грунту. Для умов досліджуваних лісостанів, які зростають у свіжому сугруді (едатоп $\mathrm{C}_{2}$ ) встановлено, що акумуляція основ, які були поглинуті у процесі біокругообігу, є найвищою у поверхневих шарах - до 3,3 мг-екв. на 100 г грунту. Суми поглинутих основ у верхніх шарах ґрунтових розрізів $€$ близькими за значеннями, аналогічну залежність встановлено також для величин ємкості поглинання.
Дані про рНн2о свідчать, що розглянуті ґрунти, в основному, мають слабокислу реакцію у верхніх шарах. 3 глибиною грунтової товщі простежується загальна тенденція до нейтралізації іiї кислотності. Слабокисла реакція $\mathrm{pH}_{\text {н2О }}$ поверхневого шару ґрунту в умовах $\mathrm{B}_{2}$ "/, $\mathrm{B}_{2}$ //' відхиляється у бік середньокислої, а в $\mathrm{C}_{3}$ - нейтральної. Дерновосередньопідзолисті ґрунти свіжих сугрудів $€$ менш кислими, ніж дерново-слабопідзолисті ґрунти свіжих суборів завдяки відсутності оглеєння та незначному вмісту рухомого алюмінію.

Найбільша кількість обмінних іонів водню та алюмінію спостерігається у поверхневому шарі - величина гідролітичної кислотності складає 9,52 мг-екв. на 100 г грунту. Ємкість поглинання цього шару найвища серед досліджуваних грунтів - 10,91 мг-екв. на 100 г грунту. За ступенем насичення основами вирізняється ґрунтова товща, де вміст цього показника коливається від 27,6\% - в елювійованій материнській породі до 82,4 \% - у моренному супіску.

Ґрунт вологого субору (едатоп В3) має значну гідролітичну кислотність, величина якої є характерною рисою цієї ґрунтової відміни. Така кислотність пояснюється переважанням анаеробних процесів протягом більшої частини року та підвищеною рухомістю півтораокислів.

Для ґрунту в умовах свіжого груду властивим $є$ наростання його насиченості поглинутими основами, зокрема Са та Mg. Сума поглинутих основ та ємкість вбирання набувають найбільших величин на глибині 0-40 cм (відповідно 8,88 мг-екв. на 100 г ґрунту та 17,9\%) проти найменших на глибині 62-100 см (4,25 мг-екв. на 100 г грунту проти $6,7 \%)$.

\section{Бібліографічні посилання:}

1. Zonn, S. V., \& Karpachevskij, L. O. (1987). Problemy lesnogo pochvovedenija i sovremennye metody lesorastitel'noj ocenki pochv [Problems of forest soil science and modern methods of forest vegetation assessment of soils]. Pochvovedenie, 9, 6-15 (in Russian).

2. Sundert, K., Horemans J., Stendahl, J., \& Vicca, S. (2018). The influence of soil properties and nutrients on conifer forest growth in Sweden, and the first steps in developing a nutrient availability metric. Biogeosciences, 15, 3475-3496. doi: org/10.5194/bg15-3475-2018.

3. Hansson, K., Laclau, J.-P., Saint-André, L., Mareschal, L., Heijden, G., Nys, C., Nicolas, M., Ranger, J., \& Legout, A. (2020). Chemical fertility of forest ecosystems. Part 1: Common soil chemical analyses were poor predictors of stand productivity across a wide range of acidic forest soils. Forest Ecology and Management, 461, 117843. doi: org/10.1016/j.foreco.2019.117843

4. Pogrebnjak, P. S. (1993). Lisova ekologija i typologija lisiv: vybrani praci. [Forest ecology and forest typology: selected works]. Naukova dumka, Kyiv (in Ukrainian). 0223-9.

5. Dollinger, J., \& Jose, S. (2018). Agroforestry for soil health. Agroforest Syst 92, 213-219. doi: org/10.1007/s10457-018-

6. Lukina, N. V., Tikhonova, E. V., Danilova, M. A., Bakhmet, O. N., Kryshen, A. M., Tebenkova, D. N., Kuznetsova, A. I., Smirnov, V. E., Braslavskaya, T. Yu., Gornov, A. V., Shashkov, M. P., Knyazeva, S. V., Kataev, A. D., Isaeva, L. G. \& Zukert, N. V. (2019). Associations between forest vegetation and the fertility of soil organic horizons in northwestern Russia. Forest Ecosystem, 6, 34. doi: .org/10.1186/s40663-019-0190-2

7. Zolotarev, S. A., \& Pohyton, O. P. (1971). Ob ob'ektyvnyh pokazateljah typov lesorastytel'nyh uslovyj sosnovyh lesov Kyevskogo Poles'ja [On objective indicators of types of forest vegetation conditions of pine forests of Kyiv Polesie]. Lesovodstvo y agrolesomelyoracyja, 27, 64-71 (in Russian).

8. Savushhyk, N. P. (1989). Vzaymosvjaz' produktyvnosty lesov y morfologycheskyh pryznakov pochv v uslovyjah Poles'ja USSR [The relationship of forest productivity and morphological features of soils in the conditions of Polesie of the Ukrainian SSR] Lesovodstvo y agrolesomelyoracyja, 78, 35-38 (in Russian).

9. Savushhyk, N. P., \& Popkov, M. Ju. (1990). Podhod k raspoznavanyju typov uslovyj mestoobytanyja sosnovyh lesov Poles'ja USSR [An approach to the recognition of the types of habitat conditions of pine forests of Polesie of the Ukrainian SSR]. Lesovodstvo y agrolesomelyoracyja, 80, 18-22 (in Russian). 
10. Savushhyk, N. P. (1989). Produktyvnost' sosnovyh lesov Poles'ja USSR v svjazy s pochvennymy uslovyjamy [Productivity of pine forests of Polesie of the Ukrainian SSR in connection with soil conditions]: Avtoref. dys... kand. s.-h. nauk: 06.03.03. / Har'kov. c.-h. yn-t ym. V.V. Dokuchaeva (in Russian).

11.Kravec, P. V. (1992). Produktyvnost' y typologycheskaja dyagnostyka sosnovyh lesov Zapadnogo Poles'ja Ukrayny. [Productivity and typological diagnostics of pine forests of Western Polissya Ukraine].: Dys... kand. s.-g. nauk: 06.03.02. Kyi'v. (in Russian).

12. Dylis, N. V. (1987). Systema pochva - fytocenoz [Soil system - phytocenosis]. Lesovedenye, 1, 3-11 (in Russian).

13. Yvanov, A. F. (1970). Rost drevesnyh rastenyj y kyslotnost' pochv. [Woody plant growth and soil acidity]. Nauka y tehnyka, Mynsk (in Russian).

14. Spurr, S. G., \& Barnes, B. V. (1984). Lesnaja ekologyja. [Forest ecology]. Pod red. S. A. Dyrenkova. Lesn. prom-st', Moskva (in Russian).

15. Uytteker, R. (1980). Soobshhestva i ekosystemy. [Communities and Ecosystems]. Progress, Moskva (in Russian).

16. Kulhavý, J., Suchomel J., \& Menšík, L. (2014). Forest Ecology Textbook. Chapter 6. Biogeochemical cycles of nutrients: 62 [Electronic resource]. Access mode: https://www.slideshare.net/MuhammadRehan124/forest-ecology-mendel-university

17. Holubík, O., Podrázský, V., Vopravil, J., Khel, T., \& Remeš, J. (2014). Effect of agricultural lands afforestation and tree species composition on the soil reaction, total organic carbon and nitrogen content in the uppermost mineral soil profile. Soil \& Water Res., 9, 192-200.

18. Panwar, P., Pal, S., Reza, S. K. \& Sharma, B. (2011). Soil Fertility Index, Soil Evaluation Factor, and Microbial Indices under Different Land Uses in Acidic Soil of Humid Subtropical India. Communications in Soil Science and Plant Analysis, 42, 27242737. doi: 10.1080/00103624.2011.622820

19. Bazylevych, N. Y., Tytljanova A. A., Smyrnov V. V., Rodyn, L. E., Nechaeva, N. T., \& Levyn, F. Y. (1978). Metody yzuchenyja byologycheskogo krugovorota $v$ razlychnyh pryrodnyh zonah [Methods of studying the biological cycle in various natural zones]. Mysl', Moskva (in Russian).

20. Vorob'jov, D. V. (1967). Metodyka lesotypologycheskyh yssledovanyj. [Methodology of forest typological studies]. Urozhaj, Kiev (in Russian).

21. Rodyn, L. E., Remezov, N. P., \& Bazylevych, N. Y. (1967). Metodycheskye ukazanyja k yzuchenyju dynamyky y byologycheskogo krugovorota $v$ fytocenozah [Guidelines for the study of dynamics and the biological cycle in phytocenoses]. Nauka, Leningrad (in Russian).

22. Smol'janynov, Y. Y. (1969). Byologycheskyj krugovorot veshhestv y povyshenye produktyvnosty lesov [Biological cycle of substances and increase of forest productivity]. Lesn. prom-st', Moskva (in Russian).

23. Kachinskij, N. A. (1975). Pochva: ejo svojstva i zhizn'. [Soil: its properties and life]. Nauka, Moskva (in Russian)

24. Jelin, Ju. Ja., Sambur, G. M., \& Pohiton, P. P. (1960). Lisoroslynni umovy lisgospu [Forest growth conditions of the forestry unit]. Rezul'taty naukovyh doslidzhen' po lisovyh kul'turah u Bojars'komu doslidnomu lisgospi. UASGN, Kyiv, 1, 22-62 (in Ukrainian).

25.Kovda, V. A. (1973). Osnovy uchenija o pochvah. Kniga vtoraja. Obshhaja teorija pochvoobrazujushhego processa. [Fundamentals of the doctrine of soils. The second book. General theory of the soil-forming process]. Nauka, Moskva (in Russian). (in Russian).

26.Remezov, N. P., \& Pogrebnjak, P. S. (1965). Lesnoe pochvovedenie. [Forest soil science]. Lesn. promyshlennost', Moskva

27.Vil'jams, V. R. (1949). Izbrannye sochinenija v 2-h t. T.2. Pochvovedenie [Selected Works in 2 volumes. Volume 2: Soil science]. Sel'hozgiz, Moskva (in Russian).

28. Kremenec'ka, Je. O. (2006). Fizyko-himichni ta agrohimichni vlastyvosti g'runtu u seredn'ovikovyh shtuchnyh sosnovyh nasadzhennjah mishanogo skladu u Dzvinkivs'komu lisnyctvi Bojars'koi' LDS Kyi'vs'koi' oblasti [Physico-chemical and agrochemical properties of soil in middle age artificial pine plantations with mixed composition in the Dzvinkivske forestry of SE "Boyarska Forest Research Station" of Kyiv region]. Lisivnyctvo Ukrai'ny v konteksti svitovyh tendencij rozvytku lisovogo gospodarstva: Materialy Mizhnarodnoi' naukovo-praktychnoi' konferencii', prysvjachenoi' 150-richchju vytokiv kafedry lisivnyctva NLTU Ukrai'ny. L'viv: NLTU Ukrai'ny, 75-76 (in Ukrainian).

Kremenetska Ye. O., PhD (Agricultural Sciences), Associate Professor, Sumy National Agrarian University, Sumy, Ukraine

Melnyk A. V., Doctor (Agricultural Sciences), Professor, Sumy National Agrarian University, Sumy, Ukraine

PHYSICOCHEMICAL PROPERTIES OF SOILS IN THE FOREST-PARK STANDS OF KYIV CITY

The experimental plots were established in natural forest stands of mature and overmature ages in different edatopes of forest growth - $A_{2}, B_{2}, B_{3}, C_{2}, C_{3}, D_{2}$ (according to Alekseev-Pogrebnyak's edaphic net). Forest stands formed mainly by Pinus sylvestris $L$. and / or Quercus robur $L$. The investigated natural forest stands are characterized by high forest plant effect, which can be explained by the favorable values of the soil's physicochemical properties $\left(\mathrm{pH}_{\mathrm{H} 2 \mathrm{O}}, \mathrm{pH} \mathrm{kCl}\right.$, amount of absorbed bases, absorption capacity, degree of saturation of bases).

The analysis of physicochemical properties of soils in the forest-park stands of the Kyiv city makes it possible to formulate conclusions. First, the numerical value of the soil-absorbing complex of sod-podzolic soils of clay-sand mechanical composition is negligible. The saturation of the soil-absorption complex by the cations of alkaline earth metals and hydrogen is evidenced by the data of the absorption capacity, which range from 4.7 to 10.7 - in the humus-eluvial horizon, as well as from 2.0 to $5.8 \mathrm{mg}-\mathrm{eq}$. per $100 \mathrm{~g}$ of soil - in eluvial horizon. The fact of decrease of this index from the upper layers to the lower ones has been established, and a considerable increase is observed at the near occurrence of moraine sediments.

Sums of absorbed bases, as well as the absorption capacity in the upper layers of all soils are close in value. The surface 
layers are characterized by significant amounts of the sums of the absorbed bases due to the accumulation of bases in the course of bio-circulation - up to $3.3 \mathrm{mg}$ - eq. per $100 \mathrm{~g}$ of soil.

In fresh submerged conditions (edatope $B_{2}$ ), the maximum value of the sum of absorbed bases was fixed in the humus-eluvial layer of the rich difference of fresh subsidence (edatope $\left.B_{2} / / I\right) ~-5,25 \mathrm{mg}-$ eq. per $100 \mathrm{~g}$ of soil; the absorption capacity in this layer reaches $10.41 \mathrm{mg}$ - eq. per $100 \mathrm{~g}$ of soil. In edatopes $B_{2}$ and $\mathrm{B}_{2}^{\prime \prime}$, the sum of absorbed bases is negligible - 0.10-2.01 mg-eq. per $100 \mathrm{~g}$ of soil, with the absorption capacity of 2.33-9.07 mg - eq. per $100 \mathrm{~g}$ of soil. Within these limits, the values of these indicators fluctuate in edatopes $A_{2}, B_{3}, C_{2}, C_{3}$. But in the deep layers of the soil profile (in places of occurrence of the mother soil), the value of this indicator increases again: in pine sand - up to $3.61 \mathrm{mg}$ - eq. per $100 \mathrm{~g}$ of soil, moraine sandy loam or loam of fresh suburbs up to 3.7, moraine light loam in edatope $C_{2}-$ up to 4.94 and in boulder clay - up to $15.5 \mathrm{mg}$ - eq. per $100 \mathrm{~g}$ of soil.

In the case of oak forest, that grow on fertile soil in fresh moisture conditions (edatope $D_{2}$ ), the sum of absorbed bases and absorption capacity have the greatest values at depths of 20-40 cm (8.88 mg - eq. per $100 \mathrm{~g}$ soil and $17.9 \mathrm{mg}-\mathrm{eq} .100 \mathrm{~g}$ soil respectively). The smallest values of these parameters were set at a depth of 62-100 cm (respectively $4.25 \mathrm{mg}-$ eq. per $100 \mathrm{~g}$ soil and $6.7 \mathrm{mg}$ - eq. per $100 \mathrm{~g}$ soil). Among the studied edatopes, the highest sums of the absorbed bases are characterized by the soil thickness of edatopes $\mathrm{C}_{2}$ and $\mathrm{C}_{3}$, where this index reaches $82 \%$.

The actual acidity ( $\mathrm{pH}_{\mathrm{H} 2 \mathrm{O}}$ ) values indicate that the upper layers of sod-podzolic soils under fresh boron conditions (edatope $A_{2}$ ) are characterized by a weak acid reaction (5.0-5.5). The magnitude of this indicator deviates toward the midacid reaction in edatopes $B_{2} /$ and $B_{2}{ }^{\prime \prime \prime}$, approaches neutral reaction (5.5-6.0) on relatively rich soils in fresh and moist conditions of moisture (edatopes $C_{2}, C_{3}$ ) - in proportion to the increase in Q. robur participation in forest stands. Such actual acidity ( $\mathrm{pH}_{\mathrm{H} 2 \mathrm{O}}$ ) contributes to the development of mycorrhizal fungi, the normal nutrition of $P$. sylvestris and its successful growth. With the depth of the soil thickness, there is a general tendency to neutralize its acidity.

The value of the exchange acidity $\left(\mathrm{pH}_{\mathrm{Kc}} \mathrm{l}\right)$ of the surface layer of soil under pine stands is within the strongly acidic (4.0-4.5), and in pine-oak forests this indicator varies between strongly acidic and slightly acidic (4.6-5.2). In the surface layer of soil of pine forest stands, $\mathrm{pH} \mathrm{KCl}_{\mathrm{I}}$ is strongly acidic (4.0-4.5), and under pine-oak forests it varies between strongly acidic and slightly acidic.

On the example of oak and pine-oak stands that are growing on fresh and moist relatively rich soils (edatopes $C_{2}$ and $C_{3}$ ) the peculiarity of distribution of actual acidity in the surface layer of soils beneath them is revealed. This feature is that the weakly acidic $\mathrm{pH} \mathrm{H}_{20}$ reaction approaches to neutral with increasing proportion of Q. robur in the stand's composition:1/10 of the total forest stand stock is Q. robur and 9/10 is P. sylvestris - pH $_{\mathrm{H} 2 \mathrm{O}}$ is $5.0 ; 3 / 10$ parts is Q. robur and 7/10 parts is $P$. sylvestris $-5.5 ; 8 / 10$ parts is $Q$. robur and $2 / 10$ parts is $P$. sylvestris $-5.7 ; 10 / 10$ parts is $Q$. robur -5.9 .

Key words: forest ecosystems, forest soil, soil properties, mature forests, Ukraine.

Кременецкая E. A., кандидат сельскохозяйственных наук, доцент, Сумской национальный аграрный университет, г. Сумы, Украина

Мельник А. В., доктор сельскохозяйственных наук, профессор, Сумской национальный аграрный университет, 2. Сумы, Украина

\section{ФИЗИКО-ХИМИЧЕСКИЕ СВОЙСТВА ПОЧВ В ЛЕСОПАРКОВЫХ НАСАЖДЕНИЯХ Г.КИЕВА}

Пробные площади закладывались в коренных лесных насаждениях спелого и перестойного возрастов в различных mипах лесорастительных условий - $A_{2}, B_{2}, B_{3}, C_{2}, C_{3}, D_{2}$ (в соответствии с эдафической сеткой Алексеева-Погребняка). Леса сформированы преимущественно Pinus sylvestris L. u / или Quercus robur L.

Исследуемые коренные насаждения характеризуются высоким лесорастительным эфффектом, который можно объяснить благоприятными величинами фризико-химических свойств почв ( $\mathrm{pH}$ н2о, $\mathrm{pH}$ ксl, суммой поглощенных оснований, ёмкостью поглощения, степенью насыщения основаниями).

Анализ физико-химических свойств почв в лесопарковых насаждениях г. Киева позволил сделать определенные выводы. Во-первых, численная величина почвенно-поглощающего комплекса дерново-подзолистьх почв глинистопесчаного механического состава является незначительной. О насыщенности почвенно-поглощающего комплекса катионами щелочно-земельных металлов и водорода свидетельствуют данные емкости поглощения, которые колеблются в пределах от 4,7 до 10,7 - в гумусово-элювиальном горизонте, а также от 2,0 до 5,8 ма-экв. на 100 г почвы - в элювиальном. Закономерным является снижение этого показателя от верхних слоев к нижним и ощутимое возрастание при близком залегании моренных отложений.

Суммы поглощенных оснований, так же, как и ёмкость поглощения в верхних слоях всех почв близки по значениям. Поверхностные слои отличаются значительными величинами, в результате аккумуляции оснований в процессе биокруговорота - до 3,3 ме-экв. на 100 г почвы.

В условиях свежей субори (эдатоп $B_{2}$ ) максимальное значение суммы поглощенных оснований зафриксировано в гумусово-элювиальном слое богатой разницы свежей субори (эдатоп B2/"I) - 5,25 м2-экв. на 100 г почвы; ёмкость

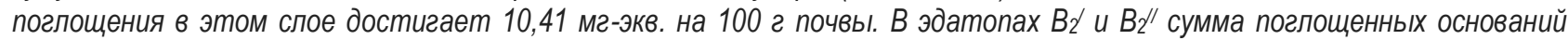
незначительна - 0,10-2,01 мг-экв. на 100 г почвы, при этом ёмкость поглощения составляет 2,33-9,07 мг-экв. на 100 г почвы. В указанных пределах величины этих показателей колеблются в эдатопах $A_{2}, B_{3}, C_{2}, C_{3}$.

Однако в глубинных слоях (в местах залегания материнской породы), величина этого показателя снова возрастает: в боровом песке - до 3,61 мг-экв. на 100 г почвы, моренной супеси или суглинке свежей субори - до 3,7, моренном легком суглинке свежего сугруда - до 4,94 и в валунной глине - до 15,5 мг-экв. на 100 г почвы.

В условиях свежей дубравы (эдатоп $D_{2}$ ) сумма поглощенных оснований и ёмкость поглощения имеют наибольшие 
величины на глубине 20-40 см (соответственно 8,88 мг-экв. на 100 г почвы и 17,9 мг-экв. на 100 г почвы). Наименьшие величины этих показателей были установлены на глубине 62-100 см (соответственно 4,25 мг-экв. на 100 г почвы и 6,7 м2-экв. на 100 г почвы). Среди исследованных эдатопов наибольшей степенью насыщения основаниями характеризуется грунтовая толща судубрав, где этот показатель достигает 82 \%.

Величины актуальной кислотности ( $\left(\mathrm{H}_{\text {нго) }}\right.$ свидетельствуют о том, что верхние слои дерново-подзолистых почв в условиях свежего бора (эдатоп $A_{2}$ ) характеризуются слабокислой реакцией $(5,0-5,5)$. Величина этого показателя отклоняется в сторону среднекислой реакции в эдатопах $B_{2}{ }^{\prime \prime}$, B2/l/ и приближается к нейтральной реакции (5,5-6,0) в свежей и влажной судубраве (эдатопы $\left.C_{2}, C_{3}\right)$ - пропорционально увеличению участия Q. robur в составе древостоев.

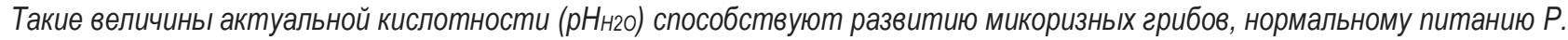
sylvestris и ее успешному росту. С глубиной почвенной толщи прослеживается общая тенденция нейтрализации ее кислотности.

Величина обменной кислотности ( $\mathrm{pH}$ ксl) поверхностного слоя почвы под сосновыми насаждениями находится в пределах сильнокислой $(4,0-4,5)$, а в сосново-дубовых лесах этот показатель колеблется между сильнокисльм и слабокислым $(4,6-5,2)$.

На примере дубовых и сосново-дубовых древостоев свежей и влажной судубравы (эдатопы С2, Сз) выявлена особенность распределения величин актуальной кислотности в поверхностном слое почвы под ними. Эта особенность

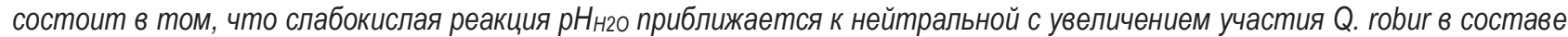
древостоев: 1 единица запаса насаждения представлена Q. robur и 9 единиц P. sylvestris - pHнго составляет 5,0; 3 единицы Q. robur и 7 единиц P. sylvestris - 5,5; 8 единиц Q. robur L. и 2 единицы P. sylvestris - 5,7; 10 единиц Q. robur - 5,9.

Ключевые слова: лесные экосистемы, лесная почва, свойства почв, спелье леса, Украина.

Дата надходження до редакції 14.05.2019 р. 